\title{
Halal Food Products and their Market Extent - Opportunities in the World
}

\author{
Dr. MUHAMMAD TARIQ KHAN \\ Associate Professor, Department of Management Sciences, \\ University of Haripur Pakistan. \\ Email: tariq_phd@yahoo.com \\ Dr. AMANULLAH KHAN \\ Assistant Professor, IBA Gomal University D.I Khan. \\ Email: amanu_khattak@hotmail.com \\ Dr. SHIRAZ KHAN \\ Assistant Professor, Department of Management Sciences, \\ University of Haripur Pakistan. \\ Email: shirazkhan@uoh.edu.pk
}

\begin{abstract}
Halal in Islam is a central concept, referring to any permissible to use e.g. thing, entity, object or action in accordance with Islamic principles \& practices, because Islam has a unique consumption \& dietary system different from other ethnic consumption \& dietary systems so what Muslims can eat is defined in halal food regulations because there are ingredients of food and processes of preparation and both must be halal, therefore all the Muslims are required to ensure that their food comes from halal sources according to principles of Shariah both its ingredients \& its whole preparation process. And now world community has recognized the importance of Muslims dietary \& other consumption needs. Muslim consumers towards halal food products have more positive intention \& attitude than non food products though halal concept is applicable to all products including food, pharmaceuticals, fashion, banking, insurance, entertainment and tourism. However what an overall concept encouraging, Muslims to seek \& use goods \& services is promoting 'cleanliness' in all the aspect of human life hence halal food is produced in a clean environment is of quality \& safe to consume. Now the term halal has attracted attention and certified halal food and other products market is increasingly growing both internationally \& domestically. Halal rules govern the tastes \& preferences of Muslim consumers so where Muslim consumers exist, market for halal food also exists. Therefore Market for halal products is very fast growing market and is to the tune of trillion dollars. This paper encompasses the points i.e. what is halal? What is origin of halal food such as animal food or plants food? What is extent of halal products market in the world?
\end{abstract}

Keywords: Halal, Food, Products, Markets, Consumption.

\section{Introduction}

For the Muslims all over the world halal food industry is of importance because of giving them a sense of security, that what they purchase, use and consume, is Shariah compliant. Halal industry also gives national economic growth and contributes to development of society (Bohari et al n.d). Shari'ah is way of life or code of conduct for Muslims around the world, applicable to every activity of Muslims including eating (Samori et al. 2014). Muslims eat permitted food and avoid what is not allowed. According to Holy Qur'an 
"And eat not of whereupon Allah's name hath not mentioned, for lo, it is abomination. Lo! The devils do inspire their minions to dispute with you, but if ye obey them, ye will be in truth idiolators" (Qur'an VI: 121). Majority of scholars are of the opinion that this verse is about slaughtering of prohibition and permission (Qureshi et al 2012). Halal concept refers to methods of producing good \& services in the manners allowed by Shariah or Islamic law Bohari et al n.d). According to Holy Qur'an \& Sunnah Muslims are strictly required to eat halal food and they are well aware of this command and it had caused to expand the halal food industry in the world. Despite of increasing revenue and halal food market importance this market segment has been ignored. Halal food has a fragmented market because every region of this market has its own characteristics different from others (Hussain et al 2014). Halal not only a religious observance and obligation for Muslims also has emerged as a powerful market force alike both for Muslims and nonMuslims so gained an increasing acceptance among Muslims along with non-Muslim consumers. Halal becoming a global symbol of lifestyle choice and quality assurance choice has promoted values as economic and social justice, earth stewardship, social responsibility, and animal welfare has gained interest which is beyond religious compliance (Elasrag 2016).

Halal business is a profitable in both Muslim countries as well as non-Muslim countries where demand for halal products is significantly growing e.g. Mexico, Russia, Japan, Thailand, South Korea and Spain, who have already established halal industrial activities. Halal business has promising opportunities and. Malaysia UAE, Bahrain, Saudi Arabia, Pakistan, Oman, Kuwait, Qatar, Jordan and Indonesia are Islamic countries in halal industry and listed according to their rank of market size (Rachman \& Syamsuddin 2019). World halal food industry is now sprouting especially is Asia, where countries have taken an initiative of traceability system \& improvement of halal standards (Nor et al, 2016). Once halal is taken as a choice of lifestyle then for halal the range of options increases exponentially (Razak et al. 2015). Religious compulsion on Muslims to consume halal drink, food, \& medicine created halal product market by stimulating halal products demand and ensuring a captive market across the world for halal meat and other products. There is US\$ 635 billion halal meat market worldwide and consumers are very happy on getting halal meat of very high quality therefore across the world halal meat is gaining popularity because of its hygienic \& scientific slaughtering and methods of processing. Method of halal slaughtering protects consumer from many diseases caused by conventional slaughtering methods applied in several countries. Halal products globally have 2 billion consumers that are yearly growing at the rate of 20 percent, so halal market in the world spans from food to tourism \& finance is worth US\$ 3 trillion (Memon, 2015). Haram \& Halal is not only restricted or limited or concerning about food, drinks \& services products but encompass all the things or matters of daily life that come in contact in daily life especially used by Muslims, such as food \& beverages, cosmetics \& pharmaceuticals, media \& communications, services like finance \& banking, tourism \& travel, garments \& fashion, and recreation, (Wahab, 2004; Murti, n.d.; Ab-Talib \& Johan, 2012; Razak et al., 2015 \& Krishnan et al 2017). Thomas Router forecasted that global Muslim food market will be worth US \$: 1626 billion, pharmaceuticals 97 billion, cosmetics 39 billion (WIFE 2015).

Figure No: 1

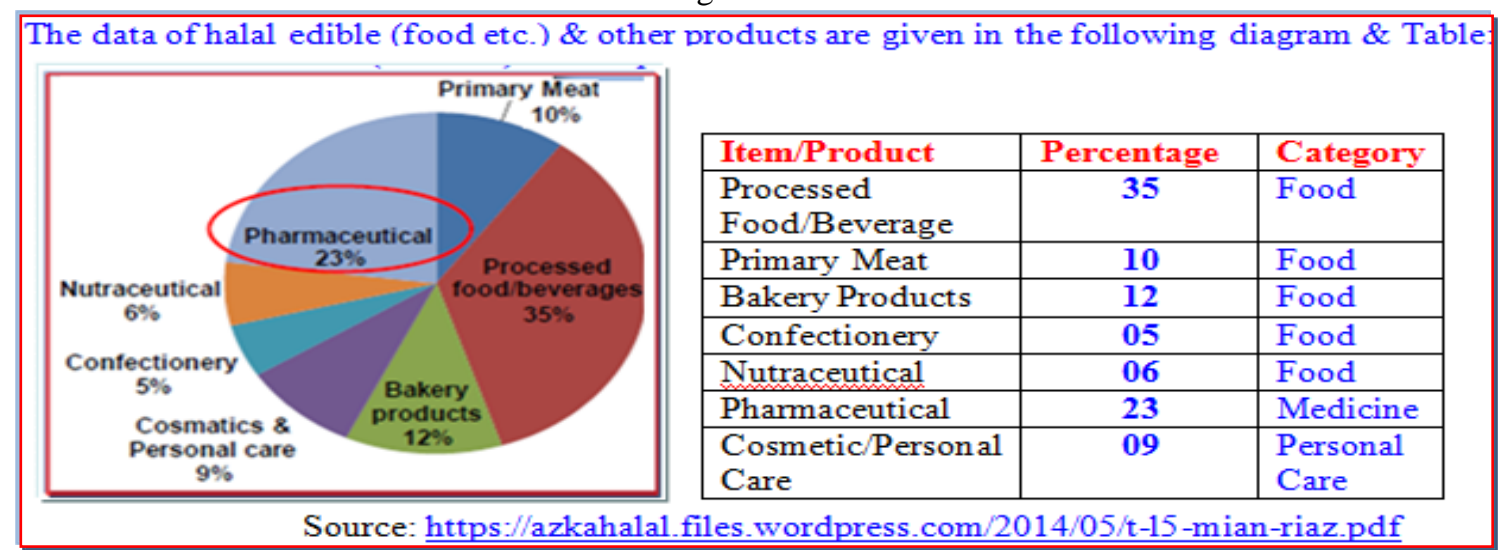




\section{What is Halal}

Kamarulzaman et al. (2016) expressed that in Islam halal is a central concept, referring to any permissible to use thing or action in accordance with Islamic principles \& practices. Batu \& Regenstein (2010) asserted that what Muslims can eat is defined in halal food regulations because there are both ingredients of food and processes of preparation that are controversial making it difficult to determine for consumer that which food is halal. Yusuf et al (2016) stated that an overall concept encouraging Muslims to seek \& use goods \& services promoting cleanliness in all the aspect of human life. Halal food means it is produced in a clean environment is of quality \& safe to consume. Yasid et al (2016); Aisyah (2017); Susilowati et al (2018) and Alzeer \& Hadeed (2020) asserted that Halal word is absorbed from Arabic language word al-halal giving meaning of permissible and refers to human entire deeds $\&$ actions or things permissible according to Islamic law. Halal food \& beverages are permissible to eat $\&$ drink while illicit ones are prohibited for human consumption. Usually halal covers or is used to describe activities that Muslims are allowed to engage in such as eating, drinking or using, seeing, wearing, talking etc. Batu \& Regenstein (2010); Samori et al. (2014); Rahim et al (2016) and Elasrag (2016) revealed that Halal term derived from Holy Quran which describes objects and actions. For each Muslim's spiritual health it is important to eat halal food. Muslims' food is expected to include healthy ingredient and not causing any harm to human body or spirit, therefore as a part of their diet Muslims must consume halal food. Fahmi (2017) narrated that halalness is a basic need of food, cosmetics, pharmaceutical (medicine) and other consumers' goods which are eaten, applied to body or used. Sugibayashi, et al (2019) asserted that among Muslims it is dictum, to consume halal goods as it is act viewed by religiosity. In the concept of Halalan-toyyiban product is considered halal, if posing no risk for health and containing wholesome ingredient for use. Golnaz et al. (2010); Ab-Talib \& Johan (2012); Rahim et al (2016) and Elasrag (2016) expressed that halal is a way of life which is not restricted to types of food consumed by Muslims who are more knowledgeable \& aware about their food for leading meaningful life. Islam being a natural way of life encompasses an economic system which is based on human brotherhood, cooperation, consultation and dietary laws. So Mohamad \& Backhouse (2014) expressed that Muslims strictly follow dietary laws and consume only halal food. In many verses Quran heavily emphasizes to consume halal and tayyub food which means good \& pure. This shows that halal concept also includes safety, quality \& hygienic aspects ensuing in Halaalan Thayibban term. In Islam generally four food and drink categories are prohibited i.e. 1- comprising itself food or drink prohibited by a clear Quranic text, 2- Halal food due to external factors transformed to haram, 3 - because of harmfulness - food harming the human body \& health, 4 - because of filthiness and impurity causing to deteriorate goodness \& wholesomeness of food.

Qureshi et al (2012); Hussain et al (2014) and Krishnan et al (2017) quoting various studies stated that the term "Halal" is designated for anything, entity, object or action which according to Quran \& Sunnah is permissible to engage in purchase, implied to body, or use. Halal denotes foods permissible according to Islamic law, e.g. Halal meat, is of halal animals slaughtered \& processed as per Islamic laws. Food is not halal in broader perspective coming in any form such as emulsifier or other forms like lecithin, enzymes, glycerin, or additives such as flavoring, coloring, stabilizers \& breadcrumbs. Quran provides a clear detail of food items which are not halal:

1 - Carrion, 2- blood, 3- swine flesh and 4- that which has been dedicated to other than Mighty Allah \& dead by beating, \& strangled, \& died by falling from height $\&$ devoured of wild beasts, killed by goring of horns, and that had been immolated idols, and that you swear by divining arrows. It is abomination (Quran V: 3 )

Annabi, \& Olajumoke (2017) mentioned that because of increasing market internalization many choices of market product consisting of new ingredients formulation are available. Based on Shariah some ingredients are not suitable for Muslim consumers because of their processing methods or sources. Annabi, \& Olajumoke (2017) further narrated that because of stress on importance of halal compliant products more transparency is demanded in halal supply chain. 


\section{Food Habits of Muslims}

Fahmi (2017) narrated that halalness is a basic need of food, cosmetics, pharmaceutical (medicine) and other consumers' goods which are eaten, applied to body or used. Elasrag (2016) asserted that Islam has a unique consumption \& dietary system different from other ethnic consumption $\&$ dietary systems and now world community has recognized the importance of Muslims dietary \& other consumption needs called halal. All the Muslims are required to ensure that their food comes from halal sources according to principles of Shariah both the ingredients \& whole food process. Now the term halal has attracted attention and for certified halal food other products market is increasingly growing both internationally \& domestically.

Halal rules govern the tastes \& preferences of Muslim consumers so where Muslim consumers exist, market for halal food also exists. Sugibayashi, et al (2019) revealed that though haram and halal concept is part of entire legal system and includes a wide range apart from food such as religiosity and attitude towards products, but often halal term is associated with food. However halal law emphasizes the permissibility of food because intake of food directly affects the development of human behavior \& wellness. Wilkins et al (2019) asserted that halal protocol for food for Muslims is most important and Muslim consumers towards halal food products have more positive intention \& attitude than non food products though halal concept is applicable to all products including food, pharmaceuticals, fashion, banking, insurance, entertainment and tourism.

Batu \& Regenstein (2010) expressed that it is the requirement of Muslims' faith to provide halal food to their families. Before Islam in Judaism kosher standards existed according to Hebrew scripture. Muslims show their respect through their food particularly poultry \& meat, where proper animal slaughtering is important. They further asserted that globally numerous ingredient of halal food industry come either from plant or animal sources. Those coming from animals are their proteins, fats, gelatin, emulsifiers, glycerin, hormones, enzymes \& some flavor compound. It is difficult to determine halalness of a product while working in modern food processing industry particularly when a product has a complex processing aids \& ingredient collection. Normally vegetable or plant products are halal if not contaminated or mixed with unlawful ingredients, or contain intoxicating material or processing aids. Everything connecting food e.g. preparation, processing, packaging \& handling, must be according to Islamic laws \& integrity of food during supply chain be maintained. No haram substance as ingredient, packaging material or packed in the same carton where halal is packed.

Elasrag (2016) asserted that Islam has a unique consumption and dietary system different from other ethnic consumption and dietary systems and now world community has recognized the importance of Muslims dietary and other consumption needs called halal. All the Muslims are required to ensure that their food comes from halal sources according to principles of Shariah both the ingredients and whole food process. Now the term halal has attracted attention and for certified halal food other products market is increasingly growing both internationally and domestically. Halal rules govern the tastes and preferences of Muslim consumers so where Muslim consumers exist, market for halal food also exists.

Buckenhüskes (2015) narrated that with regard to foodstuff based on vegetables there are no particular prohibitions and generally vegetables are halal except the poisonous plants inducing a state of intoxication. Bohari et al (n.d) asserted that MIDA (Malaysian Investment Development Authority) in 2013 valued global halal food industry between US\$ 600 billion to US\$ 2.3 trillion with estimate of rising by 2030 to 6.4 trillion.

Murti (n.d.) expressed that for food \& beverages (F\&B) Muslims spending is 17 percent of global spending amounting to US \$ 1.17 trillion \& among this food of US \$ 405 billion is halal-tayyib certified food. Muslim countries expenditure on food is given in the table below: 
Table 1: Showing Predicted Halal food Expenditure of Big Muslim Countries.

\begin{tabular}{|c|c|c|}
\hline S.No & Country & Predicted Halal Food Expenditure Billion US\$ \\
\hline 1 & Indonesia & 190 \\
\hline 2 & Turkey & 168 \\
\hline 3 & Pakistan & 108 \\
\hline 4 & Iran & 97 \\
\hline 5 & Egypt & 95 \\
\hline 6 & Bangladesh & 60 \\
\hline 7 & Saudi Arabia & 53 \\
\hline 8 & Nigeria & 38 \\
\hline 9 & Iraq & 35 \\
\hline 10 & Algeria & 35 \\
\hline \multicolumn{2}{|l}{} \\
\end{tabular}

\section{Food of Animals Origin}

Qureshi et al (2012) asserted that halal animals according to their habits are classified in to as Land Animals and Marine Animals. Examples of Land Animals are: firstly domestic animals living in homes, poultry farms and dairy farms, camel farms etc. e.g. cattle, camel, chicken, and these all are halal if properly slaughtered, secondly are wild animals as they are not domesticated, such as deer, rabit, ostrich and several birds which are halal. Among marine animals are fish and marine mammals, which if get out of water they cannot survive and die. Fish is very familiar water animal and halal even if not slaughtered. Alzeer \& Hadeed (2020) narrated that halal food is healthy food and contains all the necessary ingredients e.g. carbohydrates, fats, minerals, amino acids \& vitamins involved in production of functional proteins, DNA production and required by body for biochemical reactions.

\section{Foods of Vegetable Origin}

Buckenhüskes (2015) asserted that with regard to foodstuff based on vegetables there are no particular prohibitions and generally vegetables are halal except the poisonous plants inducing a state of intoxication.

\section{Importance of Halal Products}

Razak et al. (2015) expressed that to build a strong global halal market it is very important to aware consumer both Muslims \& non-Muslims and give wide exposure about the benefits of the halal products and services because a well-managed market of halal products $\&$ services fetches a big profit.

Susilowati et al (2018) narrated that halal concept of food has emphasis on hygiene, safety \& wholesomeness and provides an excellent opportunity for healthy eating. Because animal slaughtering process, place \& consideration, and most importantly conditions of animals being slaughtered, would not endanger the diner's health.

Adiba (2019) asserted that halal cosmetic products by consumers are considered as safe, clean \& of high quality. Halal cosmetics products do not contain any ingredient derived from alcohol, pork or their derivatives so halal products are different from generally produced cosmetics.

\section{Halal Food Market}

Hussain et al (2014) asserted that despite importance and growing revenue of halal food market, the segment of halal food market has been ignored which is not a single but fragmented market where every region has its characteristics different from other. According to Razak et al. (2015) and Krishnan et al (2017) Halal branding though for some products being in early stages is not a new concept and this concept 
of Haram \& Halal is not only restricted to products comprising product like food and drinks and services but encompasses all the matters of daily life and using halal make Muslims different from other religions. Hence while using pharmaceutical, cosmetics clothes it is to be ensured that that their ingredients are halal, even care is to be taken for environment and jobs etc. Therefore Elasrag (2016) asserted that Muslims must ensure that the source of the food they consume is halal. It means that not the ingredients themselves but the process as a whole is according to Islamic laws.

Samori et al. (2014) in a study about Malaysia narrated that as a halal hub establishment is a worldwide collective effort of many industrialists in food, cosmetics, pharmaceuticals, packaging \& logistics along with services.

Murti (n.d.) revealed that halal lifestyle is seen as new life pattern and global market needs to respond the preferences, distinctive needs, and market orientation as well as its trade \& economic values. Halal market development which is food \& beverages, cosmetics \& pharmaceuticals, media \& communications, finance, tourism \& travel, garments \& fashion, and recreation, offers a real opportunity in the region to support growth. Mutmainah (2018) narrated that total industry of halal goods \& services is of more than US \$ 1 trillion which includes, finance, beauty and hospitality \& tourism i.e. hotels and restaurants with Shariah compliance.

Wilkins et al (2019) expressing the extent of halal products market revealed that in the world Muslims' population is 1.6 billion representing 23 percent the global population and faithful Muslims consume halal products permissible under Islamic law. Market of halal products is estimated to exceed US \$2.1 trillion in value whereas annual market for only halal food is of US \$ 632 billion representing 16 percent of globally all food consumption. Besides this Wilkins et al (2019) further narrated that based in non-Muslim countries manufacturers \& retailers of food such as some non-Muslim countries fast food chains \& International restaurants like McDonald's, KFC, Subway, Pizza Express, \& Nando's now provide halal food. Bohari et al (n.d) conducted a SWOT analysis of halal market and pointed out that halal industry has 16 factors of strength, 18 factors of weakness, 9 factors of opportunities and nine factors of threat.

\section{Extent and Size of Halal Market}

Murti (n.d.) revealed that Muslim consumers are very near to halal matters relating to animal \& products. Muslims have rising trend of halal lifestyle in Islamic global trade. The worldwide increase in population \& purchasing power of Muslims and modernization era reinforces the rising tendency \& trend of halal lifestyle \& Islamic global trade. Bohari et al (n.d asserted that halal industry market for food with 1.8 billion Muslim population is estimated yearly at 547 billion dollars and this industry is capable of tremendous growth and expected to reach US\$2.1 trillion. Ab-Talib \& Johan (2012) quoting some studies narrated that 70 percent Muslim consumers follow halal standards so halal food market comprises population of 1.5 billion people giving market worth of more than US\$ 600 billion.

Abuznaid (2012) expressed that it is estimated in the world halal market is growing at annual rate of $15 \%$. Yusuf et al (2016) expressed that halal industry recently has attracted global interest, from Muslim as well as non-Muslim countries and impact of halal products affects both of them. Nor et al (2016) quoting some studies asserted that United Nations reported that after Christianity, Islam is the second largest religion with a recorded annual growth of 6.4 percent while Christianity has annual growth of 1.46 percent currently Muslims in the world are 1.62 billion representing 23.4 percent of world anticipated population of 6.9 billion for 2010 \& halal food market worth 16 percent of total world food industry, and in future estimated to be 20 percent of global food products. Asia has 63 percent, Africa 24 percent and Europe 10 percent of global market. An increasing number of customers demand halal food. 
Wilkins et al (2019) expressing the extent of halal products market revealed that in the world Muslims' population is 1.6 billion representing 23 percent the global population and market of halal products is estimated to exceed US \$2.1 trillion in value whereas annual market for only halal food is of US \$ 632 billion representing 16 percent of globally all food consumption.

Susilowati et al (2018) narrated that halal food to firms have become an attractive industry because of wide target market valued in 2015 at 661 billion US Dollars. Abuznaid (2012) and Elasrag (2016) quoting several studies revealed that it is estimated that halal industry with an annual growth rate of 15 to 20 percent is one of the fastest growing consumers segment with yearly value of US\$560 billion and total worth of US $\$ 2.3$ trillion with 1.8 billion consumers.

Nor et al (2016) further stated referring many studies that European food industry at present invested in halal food production and some Europeans produce halal products exportable to Muslim countries and some retailers need halal fresh meat for their customers. Mostly Netherland which has first of all arranged facility of storage \& warehousing is used as channel for halal products for shipping to markets in Africa, Middle East \& within Europe. All these halal products must fulfill Islamic halal criteria and be narrated as food prepared according to dietary laws of Islam which established, allowed \& prohibited food. Other aspects of halal production of halal food are animal welfare, which means separation $\&$ handling of halal animals, ritual slaughter methods, cleaning \& disinfection.

Memon (2015) revealed that religious compulsion on Muslims to consume halal drink, food, \& medicine created halal product market by stimulating halal products demand \& ensuring a captive market across the world for halal meat \& other products leading retail outlets such as Tesco, Walmart, KFC, McDonald's \& Nestle to add halal food to their products line. In the Western Hemisphere, Australia, America (USA), Canada, Brazil, France and New Zealand are major halal products suppliers, to the world, whereas in the East Indonesia, Malaysia, India, Thailand, Philippine and Singapore are big suppliers of halal certified products.

Saidon et al. (2015) highlighted that in developing countries food industry development may be considered strategic in the sense of revenue providing source as well as employment generation. It is estimated that food industry is generating $15 \%$ to $50 \%$ percent employment \& contributing $10 \%$ to $30 \%$ wealth in these countries whereas processed food export had escalated 6.6\% in 1991 to $10.6 \%$ in 2006. Memon (2015) expressed that halal products globally have 2 billion consumers that are yearly growing at the rate of 20 percent, so halal market in the world spans from food to tourism \& finance is worth US\$ 3 trillion.

Elasrag (2016) and Mohamad \& Backhouse (2014) asserted from several studies that Muslims having population of almost 1.6 billion representing 23.4 percent of global population with average growth rate of 3 percent and expected to grow $35 \%$ over next 20 years (estimates made in the year 2010) strongly adhered to principles of religion and are very sensitive in their lifestyle for halalness especially for food items so halal market has enormous prospects and to tap the extensive opportunities of halal market \& industry all business people from Muslim \& non-Muslim countries must consider many dimensions of halal concept. Halal market has huge potential \& vast opportunities for business organizations and companies because Muslim population is expected to grow @ 3\% per annum and likely to become 26.4\% of world population by 2030 and $30 \%$ by 2050. Currently 72 countries have more than one million residents but by 2030 the number would increase to 79 and Muslims will constitute even in region of Europe \& America a growing share of total inhabitants signifying enormous global halal products demand.

Mohamad \& Backhouse (2014) expressed that global halal food products' demand is estimated to be US\$ 1.5 trillion. In production of halal food there are many vibrant contributing factors including increasingly growing Muslims population, rising per capita income and high purchasing power of affluent Muslim in countries like America, Canada Middle East, Asia pacific \& European Union presenting vast opportunities $\&$ lucrative market for halal food products. Halal foods having value added features of safe, wholesome, 
contamination free principles while producing them and with additional features also attract non-Muslim consumers.

Abuznaid (2012) asserted that halal market is estimated worth US\$ 632 billion per year. Non-Muslims multinational business organizations such as Tesco, Nestle, McDonalds, \& Carrefour extended Muslim friendly offerings and command 90 percent of world halal market.

Mohamed et al (2016) are of the view that as halal food products are attributed to Islamic values so their development must be in guidance with principles of availability, legitimacy, production process purity \& accuracy must be beyond suspicion from beginning to end.

Batu \& Regenstein (2010) asserted that it is the right of consumer to obtain information with assurance of their correctness from the food producing companies \& Halal Certification System with trademark symbol provides the consumers a guarantee with much less efforts. Sugibayashi, et al (2019) narrated that globally halal cosmetics \& pharmaceuticals products are gaining awareness and increasing demand anticipated to rise until 2024 at the yearly rate of 6.8 percent.

Figure No : 2

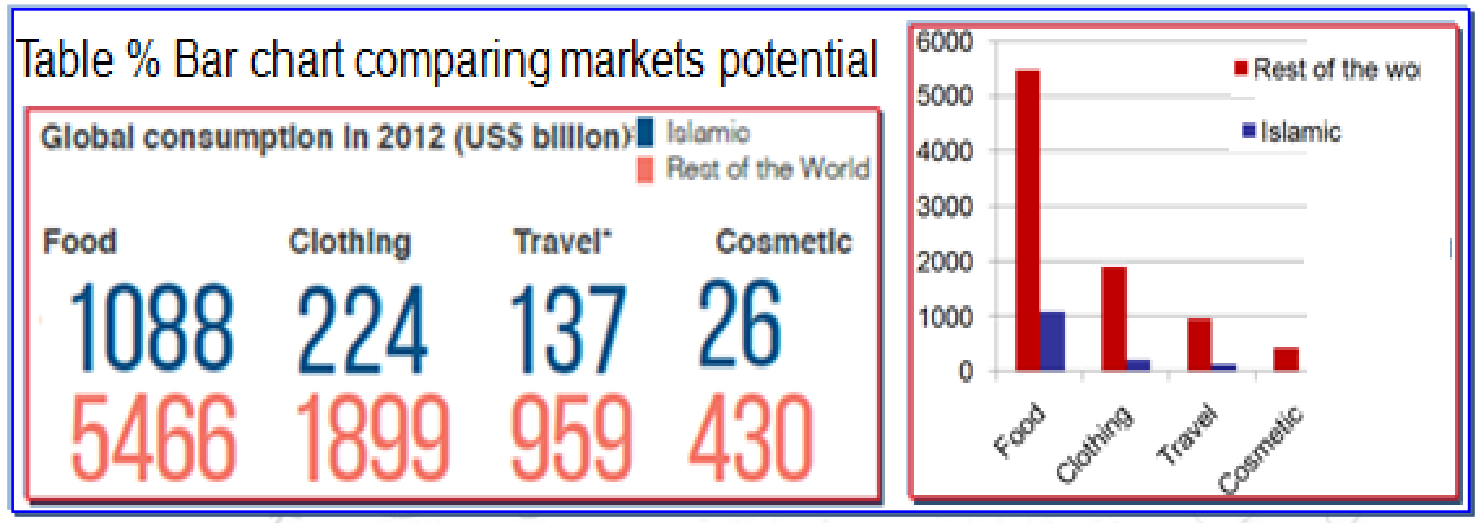

Source: WEF (2015)

WEF (2015) expressed that halal economy worldwide is growing very rapidly, and valued in 2012 approximately US \$ 3.2 trillion and was forecasted to increase to US \$ 6.4 trillion by 2018 Halal food market itself is an indicator of potential of industry. Thomas Router forecasted that global Muslim food market will be worth US \$: 1626 billion, pharmaceuticals 97 billion, cosmetics 39 billion.

Ali et al (2019) revealed quoting some studies that presently Muslims in the world are 1.8 billion but expected to $27.5 \%$ of the global population. In 2017 the expenditures of global Islamic market were US \$ 2.1 trillion of which almost US \$ 1.3 trillion were spent on F\&B (food and beverages), US \$ 207 billion on clothing \& apparel US \$ 209 billion on entertainment \& media, US \$ 87 billion on Pharmaceuticals, and finally US \$ 61 billion on cosmetics.

Sugita (2017) stated that Halal industry including food sector in recent years has significantly grown and gained much importance and halal food sector by 2019 will grow in sales US\$ 2.5 trillion becoming 21.2 percent of global food expenditure. According to a report of World Halal Forum published in 2015 the global trade estimates of food \& beverages were US\$ 1.4 trillion the global food industry is expected to rise 20 percent in near future 63 percent in Asia, 24 percent in Africa and 10 percent in Europe. Yasid et al (2016) expressed that Muslim market reached US \$ 2001 billion, in 2013, or 12 percent of global market. In 2013 for halal food Muslim Market increased to US \$ 1292 billion or 17.7 percent, of total world food market. 
Bohari et al (n.d) asserted that MIDA (Malaysian Investment Development Authority) in 2013 valued global halal food industry between US\$ 600 billion and US\$ 2.3 trillion and gave in halal food industry estimate of rising by 2030 by 6.4 trillion. It is not to focus only the halal food consumption but must also be concerned about all the supply chain process, and standard of food according to Shariah. Halal supply chain encompasses managing process of halal food products of different suppliers' points to different buyers' points located at various places especially who are simultaneously engaged in managing non halal food items with purpose of satisfying their all types of customers. Especially in the situation when Muslim food consumers became more aware and not only concern with the ingredients of the food for halal or non halal aspects but also concern about entire activities in the supply chain so ensure that their consumable product is truly halal.

Razak et al. (2015) expressed that for halal products consumer base in global market is 1.7 billion consumers and worth almost US\$2.3 trillion, making halal market as an important segment of global market. The traditional markets lying in Asia and Middle East but due to globalization effects there is significant development of halal market size in USA \& Europe.

\section{Volume or Scope of Halal Food Market}

Sugita (2017) asserted that in recent years according to a report of Thomson Reuters halal industry including halal food sector grew very significantly. Halal food sector is expected to grow till 2019 to US\$ 2.5 trillion which is 21.2 percent of world food expenditure. Likewise a report of World Halal Forum published in 2015 the global estimated halal food and beverages trade was US\$ 1.4 trillion. The halal market is worth 16 percent of total world food industry and expected to rise to 20 percent in near future with details as: 63 percent in Asia, 24 percent in Africa and 10 percent in Europe. Abuznaid (2012) revealed that estimated annual rate of growth is $15 \%$ in the world showing that halal market is fastest growing market.

Elasrag (2016) revealed that halal food is almost 20 percent of entire world food industry and in 2014 Muslim F\&B market was larger than F\&B consumption of big geographical markets, such as India US\$ 335.7 billion, Japan US\$ 367.3 billion, United States US\$ 741.2 billion \& China US\$ 797.8 billion. Geographically 16 percent of halal food consumption is in countries not member of OIC. So from Asia to America halal food sector is becoming a major source of growth and remains constant across different continents \& cultures and Nestle Malaysia is the biggest halal products producer all over the world. Saffron Road in USA is a model of success for aspiring entrepreneurs both Muslims \& non-Muslims.

Global Pathfinder Report (2011) revealed that Muslim population in the world comprising nearly 1.6 billion persons who follow halal food laws. The size of this market and its scope shows for food manufacturers a promising picture of consumers. Two drivers make halal food market first is an increasing rate of Muslim population that is 1.8 percent per year, which means increasing number of consumers especially young consumers and secondly increasing rate of GDP of Muslim countries which is faster than western countries.

Elasrag (2016) asserted further that halal food market driven by demand is continuously building its momentum across world food supply chain. According to "The State of the Global Market Economy Report 2015-16" Muslims' global expenditure on food \& beverages (F\&B) in 2013 was US\$ 1081 billion and in 2014 was US\$ 1128 billion out of total global expenditure of US\$ 6755 billion in 2014 on F\&B showing 4.3 percent increase over 2013 expenditures and amounting to almost 17 percent of global expenditure. In 2014 top Muslim countries with halal food consumption were 1 - Indonesia with US\$158 billion, 2-Turkey with US\$ 110 billion, 3 - Pakistan with US\$ 100.5 billion, and 4 - Iran with US\$ 59 billion. 


\section{Future of Food Industry}

Halal food industry has a bright future as Susilowati et al (2018) expressed that halal today is not only a religious observance or obligation but deemed for both Muslims and Non-Muslims as standard of choice worldwide.

Elasrag (2016) asserted that global halal food market is near to 20 percent of all the food industry and with increase of population and demand of consumers it is expected to become 70 percent by 2050 indication strong future of halal food products and market. Halal food industry would be a major market force due to following four trends. Firstly Islam is a very rapidly growing religion, secondly increasing demand of nonMuslim consumer due to safety and ethical reasons for instant in UK there are 6 million halal meat consumer despite there Muslim population is 2 million, similarly non-Muslim Dutch population and consumers in the Netherlands expressed their marked tendency in halal food where annual demand has reached to 3 billion US\$. The third reason is increase of Muslim population with rising disposable income and fourthly Muslim's awareness and necessity to consume halal food has increased, for example in Russia there is fast yearly increase of halal food sales between 30 percent \& 40 percent.

\section{Non- Muslim Countries export Halal Food}

Annabi, \& Olajumoke (2017) asserted that halal concept besides emerging as Muslim brand identifier, is transcending beyond a religious issue stick with Muslims, to mainstream market as a synonymous of global symbol of quality. It is believed that halal produce is safer, healthier, \& tastier appealing to even NonMuslims besides Muslims and its demand is linked to this belief.

Susilowati et al (2018) asserted that halal today is not merely a religious observance or obligation, but standard for both Muslims \& non-Muslims is considered as of choice worldwide. Elasrag (2016) expressed that halal food products a decade ago were provided in corner shops and with neighborhood butchers but now halal market has shown a universal shift in demand chain and supply chain of halal food items which are now offered increasingly in hyper market chains, grocery stores, super markets in western style, providing a wider variety of halal food products which is becoming a part of Western diet. Halal food globally has become multi billion industry hich has involved multi nationals such as Nestle, Unilever, Tesco, who extended their certified hal product lines aggressively. Nestle in Halal food sector with US\$ 5 billion yearly sales is biggest halal food manufacturer and its halal food is 35 percent of its global sales. The traditional target markets are Middle East \& Asia, besides this USA, Europe and UK are also significant halal markets which are bringing the halal in the global mainstream. However the major halal food producers are non-Muslims countries such as USA, China, Brazil, Australia and Argentina which control 90 percent of world halal market. It is further to elaborate that Malaysia a Muslim country, Muslim consumers spend 14 percent of their food expenses on meat and 60 percent of Malaysian meat are imported from non-Muslim countries i.e. Australia, India and New Zealand who have established them as halal meat and poultry market leader. Similarly Saudi Arabia, Egypt, Algeria, also import meat for their local consumption from non-Muslim countries. Mohamad \& Backhouses (2014) are of the opinion that halal food sector is not only an industry complying religious requirements but an economic force globally and domestically in its rights. Countries having Muslim minority but exporting food for income generation found necessity of being aware about halal such as China which exports US \$ 500 billion products in halal market. Susilowati et al (2018) revealed that worldwide almost all exporters of halal meat are from nonMuslim countries e.g. Australia, Argentina, Brazil, France, Canada, and New Zealand. Elasrag (2016) asserted that the cosmetic industry all over the world is dominated and to some extent monopolized by nonMuslim companies posing a serious challenge to matter of halal ingredients in their manufactured cosmetic products. Batu \& Regenstein (2010) expressed that halal products certified responsibly are gaining acceptance as a bench mark for quality and safety assurance. 


\section{Conclusion}

From the study of above quoted literature it is concluded that:

1 - Islam has a unique consumption \& dietary system different from other ethnic consumption \& dietary systems because 'halal rules' govern the tastes \& preferences of Muslim consumers. So Muslim consumers have more positive intention \& attitude towards halal food products than non food products though halal concept is applicable to all products including food, pharmaceuticals, fashion, banking, insurance, entertainment and tourism.

2 - Halal is a central concept in Islam, referring to any permissible to use thing or action in accordance with Islamic principles \& practices (Shariah). And what Muslims can eat is defined in halal food regulations because there are both ingredients of food and processes of preparation of food both are required to be halal.

3 - Halal concept of food lays emphasis on hygiene, safety \& wholesomeness and provides an excellent opportunity for healthy eating.

4 - World Muslims' population is estimated from 1.6 billion to 1.8 billion and 2 billion according to some researchers representing 23 to 25 percent the global population and faithful Muslims consume halal products.

5 - Market of halal products is estimated to exceed US \$ 2.1 trillion in value whereas annual market for only halal food is of US $\$ 632$ billion representing 16 percent of globally all food consumption.

6 - Therefore halal food products for firms have become an attractive industry because of wide target market valued in at US \$ 632 billion to US \$ 661 billion.

7 - It is estimated that halal industry with an annual growth rate of 15 to 20 percent is one of the fastest growing consumers segment with total worth of US $\$ 2.3$ trillion with 1.8 billion consumers.

8 - It is also estimated that food industry is generating $15 \%$ to $50 \%$ percent employment \& contributing $10 \%$ to $30 \%$ wealth in these countries whereas processed food export had escalated $6.6 \%$ in 1991 to $10.6 \%$ in 2006.

9 - Halal today is not only a religious observance or obligation but deemed for both Muslims and NonMuslims as standard of choice worldwide.

Therefore halal food products have almost market prospects to the tune of US \$ 660 billion and Muslim countries should pay attention towards this lucrative marketing opportunity and try to gain their due market share as presently it is benefitting to non-Muslim countries which export Halal food products.

\section{References}

Ab Talib, Mohamed S and Johan, M, Remie M. (2012) "Issues in Halal Packaging: A Conceptual", International Business and Management, Vol. 5, No. 2, pp. 94-98, 2012

الـ د سوي ق ,الإ سدامي الـ سوق Abuznaid, Samir (2012) "Islamic Marketing: Addressing the Muslim Market" An - Najah Univ. J. Res. (Humanities), Vol. 26(6), 2012.

Adiba, E M. (2019) "Consumer Purchasing Behavior of Halal Cosmetics: A Study on Generations X \& Y", Journal of Islamic Monetary Economics \& Finance, Vol. 5, No.1, pp. 169-192,

Ahmad, J (2014) "The Role of Public Relations in Promoting Islamic Products Globally: The Malaysian Experience", Journal of Islamic Studies and Culture, Vol. 2(3), pp. 63-81.

Aisyah, Muniaty (2017) "Consumers Demand on Halal Cosmetics and Personal Care Products in Indonesian”, Al-Iqtishad: Journal Ilmu Ekonomi Syariah (Journal of Islamic Economics) Vol. 9 (1), January 2017, pp. 125 - 142

Ali, Q.; Salman, A.;Yaacob, H. and Parveen, S. (2019) "Financial Cost and Social Influence: Factors Affecting the Adoption of Halal Cosmetics in Malaysia", Academy of Entrepreneurship Journal. Vol. 25(2), 2019. 
Alzeer, J. and Hadeed, K. Abou (2020) "Halal Certification of Food, Nutraceuticals, \& Pharmaceuticals in the Arab World" I. Laher (ed.), Handbook of Healthcare in the Arab World, Springer Nature Switzerland AG 2020, https://doi.org/10.1007/978-3-319-74365-3_36-1

Batu, A. and Regenstein, J. M. (2010) "Halal Food Certification Challenges and their Implications for Muslim Societies Worldwide" (2010) Turkish Studies - International Periodical for the Languages, Literature and History of Turkish or Turkic Vol. 9, No. 11, fall 2014, pp. 111-130, Ankara-Turkey.

Bohari, A.; M.; Cheng W. \& Hin, N. F. (n.d) "The competitiveness of Halal Food industry in Malaysia: A SWOT - ICT analysis", Malaysia Journal of Society \& Space Vol. 9(1), pp. 1 - 9

Buckenhüskes, Prof. Dr. H. J. (2015) "Halal foodstuffs: Halal market - Religious, Background Certification", DLG-Expert report 6/2013: @ 2015, www.DLG.org

Elasrag, Hussein (2016) "Halal Industry: Key Challenges and Opportunities”, MPRA Paper No. 69631, Munich Personal RePEc Archive, 2016, https://mpra.ub.uni-muenchen.de/69631/

Fahmi, Syaifuddin (2017) "Halal Labeling Effect on Muslim Consumers Attitude and Behavior'International Conference of Organizational Innovation (ICOI 2017), Advances in Intelligent Systems Research, Vol. 131.

Global Pathfinder Report (2011) “Halal Food Trends”, Market Indicator Report, (C Her Majesty the Queen in Right of Canada, 2011, ISSN 1920-6615 Market Indicator Report. AAFC No. 11441E, International Markets Bureau, Market Indicator Report, April 2011

Golnaz, R; Zainalabidin, M. and Mad Nasir S. (2012) “Assessment of Consumers' Confidence on Halal Labelled Manufactured Food in Malaysia”, Pertanika Journal of Social Sciiences \& Humanity, Vol. 20(1), pp. 33 - 42 (2012).

Hussain, N.; Haq A.; M; Zafar-uz-Zaman \& Usman, M. (2014) "Global Halal Food Market and Opportunities for Pakistan”, International Journal of Education \& Research Vol. 2(3),

Kamarulzaman,Y; Veeck, A; Mumuni, A G.; Luqmani, M and Quraeshi, Z.A (2016) "Religion, Markets, and Digital Media: Seeking Halal Food in the U.S.” Journal of Macro-marketing 2016, Vol. 36, No. 4, pp. 400-411

Krishnan, S; Che M. Che O.; Irsyad Z;; Nazreen S. \& Sharifah A. (2017) “The Awareness of Gen Z's toward Halal Food Industry", Management 2017, Vol. 7(1), pp. 44-47.

Memon, Dr. Noor Ahmed (2015) "Demand grows for Pakistani Halal Meat", Exclusive on Meat, July Auguas-2015, https://www.foodjournal.pk/2015/July-August-2015/PDF-July-August-2015/Dr-Noorhalal-meat.pdf

Mohamad, Norizah and Backhouse, Chris (2014) "A Framework for the Development of Halal Food Products in Malaysia", Proceedings of the 2014 International Conference on Industrial Engineering and Operations Management Bali, Indonesia, January 7 - 9, 2014.

Mohamed,Y.H.; Abd Rahman A. R; Azanizawati B. M; and Mohd G. H. (2016) "Halal Traceability in Enhancing Halal Integrity for Food Industry in Malaysia-A Review”, International Research Journal of Engineering and Technology, Vol.: 03 (3) Mar-2016.

Murti, Tridjoko Wisnu (n.d.) "Halal Life Style and Global Trade", The 7th International Seminar on Tropical Animal Production Contribution of Livestock Production on Food Sovereignty in Tropical Countries September 12-14, Yogyakarta, Indonesia

Mutmainah, Lu'liyatul (2018) The Role of Religiosity, Halal Awareness, Halal Certification, and Food Ingredients on Purchase Intention of Halal Food", Journal of Islamic Economics, Finance, and Banking, Vol.1, No 1\&2, Juni-Desember 2018, pp. 33-50.

Nor, Dr. M. R. M.; Kashif L.; Dr. Mohd N. I. \& Nor, Dr. M. N. (2016) “Critical Success Factors of Halal Supply Chain Management from the Perspective of Malaysian Halal Food Manufacturers", Arabian Journal of Business \& Management Review, Vol. 4(1), 2016.

Qureshi, S. S.; Jamal, M; M. S. Qureshi, M. Rauf, B. H. Syed; M. Zulfiqar and N. Chand (2012). "A Review of Halal Food with Special Reference to Meat and its Trade Potential", The Journal of Animal and Plant Sciences, Vol. 22(2), Suppl, 2012, pp. 79-83.

Rachman, M. Auli \& Syamsuddin (2019) "Halal Industry in Indonesia: The Role of Sharia Financial Institutions in Driving Industrial and Halal Ecosystem”, Al-Iqtishad: Jurnal Ilmu Ekonomi Syariah (Journal of Islamic Economics) Vol.11 (1), January 2019. 
Razak, M. I. M; Alias, Z; Samad I. H. A; Naseri, R. N. N.; Ahmad, N. Z. A. \& Baharuddin, F N. (2015) "Overview of Halal Products and Services in Malaysia and Global Market" International Journal of Economics, Commerce and Management, Vol. III(3), 2015.

Saidon, Intan Marzita; Radzi, Rafisah Mat and Ghani, Nadzri Ab (2015) "Food Supply Chain Integration: Learning From the Supply Chain Superpower", International Journal of Managing Value and Supply Chains, Vol. 6, No. 4, December 2015.

Samori, Zakiah; Ishak, Amal Hayati and Kassan, Nurul Himmah (2014) "Understanding the Development of Halal Food Standard: Suggestion for Future Research”, International Journal of Social Science and Humanity, Vol. 4, No. 6, November 2014.

Sugibayashi, K; Eddy Y; Hiroaki, T; Sabrina D; Pajaree S; Florencio Jr Arce; and Gerard Lee See (2019) "Halal Cosmetics: A Review on Ingredients, Production, and Testing Methods", Cosmetics 2019, Vol. 6(37), www.mdpi.com/journal/cosmetics

Sugita, Ira (2017) "Halal in Singapore" Global Agricultural Information Network (GAIN). Report: SN7004, Prepared by Ira Sugita, Agricultural Specialist dated March 28, 2017

Susilowati, I., Edy, R; E., Kirana, M., Mafruhah, I., \& Radam, A. (2018) The Economic \& Sharia Value of Moslem's Awareness for Halal Food in Indonesia, Jurnal Ekonomi Pembangunan: Kajian Masalah Ekonomi dan Pembangunan, 19(1), 102-113.

Wahab, Dr. A. R. (2004) "Guidelines for the Preparation of Halal Food \& Goods for the Muslim Consumers", HALAL Guidelines for manufacturer, 2004, AmalMerge (M) Sdn. Bhd

WIFE (2015) "When Halal Meets Islamic Finance" The WIEF Chronicles, the World Economic Forum (WIFE) Foundation, Issue 14, January 2015

Wilkins, S.; Butt, M. M.; Shams, F. \& Pérez, A. (2019) "The acceptance of halal food in non-Muslim countries: effects of religious identity, national identification, consumer ethnocentrism \& consumer cosmopolitanism", Journal of Islamic Marketing, Vol. 10(4), pp. 1308-1331.

Yasid; Farhan, Fikri and Andriansyah (2016) "Factors Affecting Muslim Students Awareness of Halal Products in Yogyakarta, Indonesia”, International Review of Management and Marketing, 2016, 6 (S4) 27-31, Special Issue for "Asia International Conference (AIC 2015), 5-6 December 2015, Universiti Teknologi Malaysia, Kuala Lumpur, Malaysia”.

Yusuf, A. H; Shukor, S A \& Bustamam, U. Salwa A. (2016) "Halal Certification Vs Business Growth of Food Industry in Malaysia”, Journal of Economics, Business \& Management, Vol. 4(3), March 2016. 